\title{
INFLUENCE OF FOLIAR FERTILISERS ON BIOCHEMICAL AND PHYSIOLOGICAL PROPERTIES IN NEPETA RACEMOSA LAM.
}

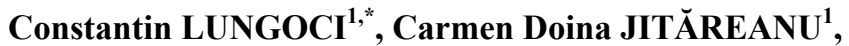 \\ Carmen Simona GHIȚĂU ${ }^{1}$, Teodor ROBU ${ }^{1}$
}

*E-mail: constantinlungoci@uaiasi.ro

Received: 18 Nov. 18, 2021. Revised: Feb. 06, 2022. Accepted: Feb. 09, 2022. Published online: Feb. 23, 2022

\begin{abstract}
The purpose of this study was to evaluate some elements of physiology and biochemistry in Nepeta racemosa Lam. in the pedo-climatic conditions of the Moldavian forest steppe. The parameters were quantified under conditions of differentiated fertilisation with three foliar products (KSC 1, KSC 2, and Corona K). Biochemical analysis by GC/MS revealed the highest concentration of the following components: nepetallic acid (Untreat - 54.33\%, KSC 1 - 55.50\%, KSC 2 $56.90 \%$, Corona K - 53.77), eucalyptol (Untreat . 9.87\%, KSC $1-10.70 \%$, KSC 2$12.80 \%$, Corona K - 10.78\%), 3-hydroxy(4S, 4aS, 7S, 7aS)-dihydronepetalactone (Untreat - 5.87\%, KSC 1 - 5.37\%, KSC 2 4.87, Corona K - 3.67\%), and (4aS, $7 \mathrm{~S}$, 7aS)-trans, cis-nepetalactone (Untreat $4.30 \%$, KSC $1-5.00 \%$, KSC $2-4.20 \%$, Corona K - 5.23\%). Polyphenols were present in large quantities in the Corona $\mathrm{K}$ variant, with $33.1 \mathrm{mg} \mathrm{GA} / \mathrm{g} \mathrm{dw}$ at the first harvest and $27.88 \mathrm{mg} \mathrm{GA} / \mathrm{g} \mathrm{dw}$ at the second harvest. The highest concentration of flavonoids was identified in the Corona $\mathrm{K}$ variant $(26.34 \mathrm{mg} \mathrm{QE} / \mathrm{g} \mathrm{dw}$ - first harvest and $56.77 \mathrm{mg} \mathrm{QE} / \mathrm{g} \mathrm{dw}$ - second harvest). The antioxidant activity was between 14.76 and $38.54 \%$ at the first harvest, and
\end{abstract}

from 12.18 to $22.95 \%$ at the second harvest. Chlorophyll pigments ranged from 13.12$17.68 \mu \mathrm{g} / \mathrm{ml}-1$ for chlorophyll $a$, 5.43-9.66 $\mu \mathrm{g} / \mathrm{ml}^{-1}$ for chlorophyll $b$, and 2.07-3.34 $\mu \mathrm{g} / \mathrm{ml}^{-1}$ for carotenoids. The highest grass production per $\mathrm{m}^{2}$ was achieved in the version fertilised with KSC 1 for both crops, with $986.66 \mathrm{~g} / \mathrm{m}^{2}$ for the first harvest and $861.33 \mathrm{~g} / \mathrm{m}^{2}$ for the second. Iridoids are a class of substances that are commonly used for pesticide role. The study aims to highlight these substances and determine whether differentiated fertilization influences. The presented data confirm the results in the literature for polyphenols and flavonoids, but also present chemotypic novelties in terms of chemical composition and represent a direction to follow for future research.

Keywords: nutrients; flavonoids; nepetalic acid; polyphenols; chlorophyll; DPPH.

\section{INTRODUCTION}

In the current context of promoting environmentally friendly products, acclimatisation and introduction into the culture of new species with a diversified

\footnotetext{
1 University of Life Sciences, lasi, Romania
} 
chemical composition is imperative, especially since Nepeta racemosa Lam. is little researched in our country.

The growing interest in natural products has led to research, acclimatisation, and the introduction of some species that have been neglected until recently. Studies show that these are a reservoir of bioactive principles that is currently underutilised. An increasing amount of research confirms certain medical, food, and additive properties, which in the past were used only in isolation or in traditional systems. Today's society is aware of the negative effects that synthetic products have and is trying to find alternatives in nature for the needs they face.

In the Kingdom Plantae, the Lamiaceae family is the most expressive, with many economic valences from which secondary metabolites are widely used in many industrial fields (Salehi et al., 2018).

The Nepeta (Lamiaceae) genus contains about 280 species that are widespread from central and southern Europe to southern Asia (Dabiri and Sefidkon, 2003). In our country, the species Nepeta cataria L., N. parviflora M. Bieb, N. nuda L. (N. pannonica L.), and $N$. ucranica L. have been identified (Sârbu et al., 2003).

Different species of the genus Nepeta are used due to their antiasthmatic, antitussive, antioxidant (Azizian et al., 2021), diuretic, antipyretic, expectorant (Kordali et al., 2015), antispasmodics (Rather et al., 2012), insecticidal, acaricidal (Çalmaşur et al., 2006), antifungal (Sonboli et al., 2004) and cytostatic properties (Al-Oqail et al., 2014), among others.

Due to the allelopathic substances they release in the soil, many species have been studied to obtain bioherbicides (Mutlu et al., 2010), and in the case of some weeds, results have been obtained that can be extrapolated in agricultural practice.

Studies conducted by Peterson and Coats (2001) show that some biochemical components in the volatile oil of Nepeta species - nepetalactones - have a repellent action similar to that of DEET, but unlike this synthetic product, volatile oil has no side effects on the body and is more environmentally friendly.

Dabiri and Sefidkon indicated that Nepeta racemosa Lam. is synonymous with other species, such as $N$. transcaucasica Grosch., N. elbursensis Rech. F., N. mussinii Spreng., $N$. grandifolia M.B. and N. marifolia Boiss. \& Huet. It has recently acclimatised in our country and has a high ecological plasticity and a diversified biochemical composition. Its main constituents are increasingly found in pharmaceutical and organic plant protection products, as well as in the food industry.

Through this study, we aimed to determine if crop area and fertilisers have a major influence on the determined parameters. Knowing these details can give us information about the ecological plasticity of the species, and the biochemical composition gives us data on suitability in certain industries (food, plant protection products, additives, etc.). In addition to the general determinations, this study aimed for continuity, and the next proposed step is to determine the bioherbicide effect.

\section{MATERIALS AND METHODS}

\section{Experimental design}

The experiment was located in the research fields of the discipline of Medicinal 


\section{Constantin LUNGOCI, Carmen Doina JITĂREANU, Carmen Simona GHIȚĂU, Teodor ROBU}

and Aromatic Plants of the Iaşi University of Life Sciences (IULS). It was arranged in the form of random plots with three repetitions. Each variant had an area of $9 \mathrm{~m}^{2}$. The species Nepeta racemosa Lam. was purchased from the Botanical Garden "Alexandru Ciubotaru", Chisinau, Republic of Moldova, and multiplied in our fields.

The soil on which it was placed is cambic chernozem with a content of $3.3 \%$ humus, a weakly acid reaction with the following arrangement of horizons: $\mathrm{A}_{\mathrm{p}}-\mathrm{A}_{\mathrm{tp}}{ }^{-}$ $\mathrm{A}_{\mathrm{m}}-\mathrm{B}_{\mathrm{v} 1}-\mathrm{Bv}_{2}-\mathrm{Bvk}-\mathrm{BC}_{\mathrm{k}}-\mathrm{C}_{\mathrm{ca}}$. Humus has a decreasing distribution. The $\mathrm{A}_{\mathrm{p}}$ horizont has $16 \mathrm{~cm}$, the $A_{t p}$ has $10 \mathrm{~cm}, A_{m}-19 \mathrm{~cm}, B V_{1}-$ $7 \mathrm{~cm}, \mathrm{~B}_{\mathrm{v} 2}-14 \mathrm{~cm}, \mathrm{~B}_{\mathrm{ve}}-6 \mathrm{~cm},(\mathrm{BC})_{\mathrm{k}}-15 \mathrm{~cm}$, $\mathrm{C}_{\mathrm{ca}}-25 \mathrm{~cm}$ (Filipov, 2005; Botnar, 2011).

The foliar fertilisers used were KSC 1 $(14 \% \mathrm{~N} ; 40 \% \mathrm{P} ; 5 \% \mathrm{~K}+13 \% \mathrm{~S}+0.1 \% \mathrm{Fe}+$ $0.05 \% \mathrm{Cu}+0.1 \% \mathrm{Zn}+0.1 \% \mathrm{~B}+0.01 \%$ Mo), KSC $2(23 \% \mathrm{~N} ; 5 \% \mathrm{P} ; 5 \% \mathrm{~K}+29 \% \mathrm{~S}$ $+0.1 \% \mathrm{Fe}+0.05 \% \mathrm{Mn}+0.1 \% \mathrm{Zn})$ and Corona K $(9 \% \mathrm{~N} ; 11 \% \mathrm{P} ; 39 \% \mathrm{~K}+7 \% \mathrm{~S}+$ $0.1 \% \mathrm{~B}+0.1 \% \mathrm{Cu}+0.1 \% \mathrm{Fe}+0.1 \% \mathrm{Mn}+$ $0.01 \% \mathrm{Mo}+0.1 \% \mathrm{Zn}$ ). The foliar fertiliser was administered at a dose of $3 \mathrm{~kg} / \mathrm{ha}^{-1}$, in the budding-onset flowering phenophase. The control variants were only treated with distilled water (Pavela et al., 2018). The samples were collected 5 days after the treatments (June for the first harvest and the end of September for the second harvest).

\section{Climate conditions}

From a climatological point of view, the year 2021 was characterised by a very rich rainfall regime; in all months, the amount of precipitation was above the multiannual average. In the case of temperature, they fluctuated around the multiannual average (Table 1).

In the case of precipitation, the largest deviation from the multiannual average was in August with a value of $+98 \mathrm{~mm}$ and the lowest in July of $+0.3 \mathrm{~mm}$.

In the case of temperature, they closely followed the multiannual values. The biggest difference was $+2.1^{\circ} \mathrm{C}$ in July, and the smallest difference occurred in May and August and was $\pm 0.5^{\circ} \mathrm{C}$.

Table 1 - Climatic conditions of 2021

\begin{tabular}{rccccccc}
\hline & III & IV & V & VI & VII & VIII & IX \\
\hline$\sum \mathrm{mm}$ & 29.2 & 44.8 & 55.8 & 83.7 & 71.3 & 57.4 & 47.0 \\
\hline $\mathbf{2 0 2 1}$ & $\mathbf{6 5 . 4}$ & $\mathbf{5 6 . 4}$ & $\mathbf{8 7}$ & $\mathbf{1 1 5}$ & $\mathbf{7 1 . 6}$ & $\mathbf{1 5 5 . 4}$ & $\mathbf{1 2 . 4}$ \\
\hline Avarage ${ }^{\circ} \mathrm{C}$ & 2.7 & 9.9 & 15.7 & 19.2 & 21.1 & 20.4 & 16.1 \\
\hline $\mathbf{2 0 2 1}$ & $\mathbf{3 . 7}$ & $\mathbf{8 . 3}$ & $\mathbf{1 5 . 2}$ & $\mathbf{1 9 . 8}$ & $\mathbf{2 3 . 2}$ & $\mathbf{2 0 . 9}$ & $\mathbf{1 4 . 6}$ \\
\hline
\end{tabular}

\section{Biochemical analysis}

The volatile oil required for biochemical analysis was obtained by hydrodistillation with the NeoClevanger apparatus for $4 \mathrm{hrs}$ (Romanian Pharmacopoeia, 2008).

The chemical composition was determined by GC-MS (gas chromatography coupled with mass spectrophotometry using an Agilent Technologies type $6890 \mathrm{~N}$ chromatograph together with a mass detector (MSD) type 5975 inert XL Mass Selective Detector. Column DB5 was also used (30 $\mathrm{mx} 0.25 \mathrm{~mm}$ ) with an inner size of $0.25 \mu \mathrm{m}$ (5\% phenylmethylsiloxane). The following parameters were used: gas carrier helium
$1 \mathrm{~mL} / \mathrm{min}$, injector temperature $220^{\circ} \mathrm{C}$, detector temperature $250^{\circ} \mathrm{C}$, initial temperature $60^{\circ} \mathrm{C} \mathrm{(3} \mathrm{deg./min)} \mathrm{up} \mathrm{to} 246^{\circ} \mathrm{C}$ (constant $8 \mathrm{~min}$ ) and volume injected between $0.1-0.3 \mu \mathrm{L}$ The NIST 2008 database based on mass spectrum and retention time was used to identify peaks (Adams, 2007).

Quantitative determination of assimilative pigments was performed from $0.5 \mathrm{~g}$ samples of fresh material, using acetone as a solvent $(80 \%)$ (Buhăianu and Jităreanu, 2018). The data obtained were processed according to Lichtenthaler's equations (Lichtenthaler, 1987; Wellburn, 1994). 


\section{EVALUATION OF SOME ELEMENTS OF PHYSIOLOGY AND BIOCHEMISTRY IN NEPETA RACEMOSA LAM.}

Samples for the determination of polyphenols, flavonoids, and antioxidant activity were prepared from $0.5 \mathrm{~g} /$ fresh herb incubated for $24 \mathrm{hrs}$ with $95 \mathrm{ml}$ ethyl alcohol $(95 \%)$. The filtered product was used in the other analyses. The readings were performed on a UV/Vis spectrophotometer, DLAB PS-V1100.

To establish total polyphenols, $0.1 \mathrm{ml}$ of the leaf sample incubated with $0.1 \mathrm{ml}$ of Folin-Ciocâlteu reagent was used (Merck USA); then $7.5 \% \mathrm{NaCO}_{3}$ was added, and after a 90 min incubation, the samples were read using the spectrophotometer at a wavelength of $760 \mathrm{~nm}$. To interpret the results, a calibration curve was performed using different concentrations of gallic acid per gram of dry matter (Teliban et al., 2020). The total flavonoid content was assessed by absorbing the sample at $510 \mathrm{~nm}$, resulting from the extract in combination with 5\% $\mathrm{NaNO}_{2}$ and $10 \% \mathrm{AlCl}_{3}$. The interpretation of the results was performed according to the calibration curve obtained from different concentrations of quercetin and expressed in quercetin equivalents per gram of dry matter (Lobiuc et al., 2017).

According to the method described by Onofrei et al. (2017), the antioxidant activity was assessed using DPPH reagent (2,2-diphenyl-1-picrylhydrazyl) in an amount of $2.9 \mathrm{ml}$ mixed with $0.1 \mathrm{ml}$ of plant extract. The values recorded by the spectrophotometer at a wavelength of $515 \mathrm{nM}$ were read after the samples were kept in the dark for 180 min.

Data processing was performed according to the following formula:

$$
\text { DPPHsc } \%=\frac{(\text { Abs control })_{t=x \min }-(\text { Abs sample })_{t=x \min }}{(\text { Abs control })_{t=x \min }} \times 100
$$

where, Abs control is the absorbance of DPPH solution mixtures without the extract, and Abs simple is the absorbance of DPPH mixtures containing the extract.

The production calculation was performed by determining the amount of biomass per $\mathrm{m}^{2}$.

\section{Statistical analysis}

The results obtained are presented as averages and standard errors. To assess statistically significant differences between treatments, averages were compared using unidirectional analysis of variance (ANOVA). When the results were statistically significant, the post-hoc Tukey multiple comparison test was used. The main difference was set to be significant at $p<0.05$. The software used for statistical analysis was IBM SPSS v14.

\section{RESULTS AND DISCUSSION}

\section{Biochemical analysis}

The first biochemical investigations of Nepeta species were conducted in 1955 (McElvain and Eisenbraun, 1955).
The chemical composition was very different from the results confirmed by other authors (Table 2). This was also confirmed in the species Nepeta racemosa Lam. The term chemotype indicates that plants that have developed a chemically different composition depending on the pedo-climatic conditions. In the following we exemplify with some results obtained by other authors, the diversity of the chemical composition in $N$. racemosa Lam.: nepetalactone, $4 \mathrm{a} \alpha, 7 \alpha, 7 \mathrm{a} \alpha$ $64.9 \%$ under the conditions in Iran (Dabiri and Sefidkon, 2003); nepetalactone, $4 \mathrm{a} \alpha, 7 \beta, 7 \mathrm{a} \alpha-81.1 \%$ (Işcan et al., 2011), nepetalactone, $4 \mathrm{a} \alpha$, $7 \beta, 7 \mathrm{a} \alpha-81.1 \%$ (Morteza-Semnani and Saeedi, 2004); 4a $\alpha, 7 \alpha, 7 \mathrm{a} \alpha$-nepetalactone - 64.9\% (Rustaiyan et al., 2000); and $4 \mathrm{a} \alpha, \quad 7 \alpha, \quad 7 \mathrm{a} \alpha$-nepetalactone - $28.1 \%$ (Mohammadhosseini, 2016).

The predominant component in volatile oil is nepetalic acid, which has the highest percentage in nitrogen- 


\section{Constantin LUNGOCl, Carmen Doina JITĂREANU, Carmen Simona GHIṬĂU, Teodor ROBU}

fertilised varieties (56.9\%). Similar reports were made by Harney et al. (1978) at $43 \%$ nepetalic acid in Nepeta cataria L.

The second predominant component was eucalyptol, which also had the highest concentration in the nitrogen- fertilised variant $(12.8 \%)$. The third most predominant compound, 3-hydroxy-(4S, 4aS, 7S, 7aS)-dihydronepetalactone, had the highest concentration $(5.37 \%)$ in the nitrogen-fertilised variant.

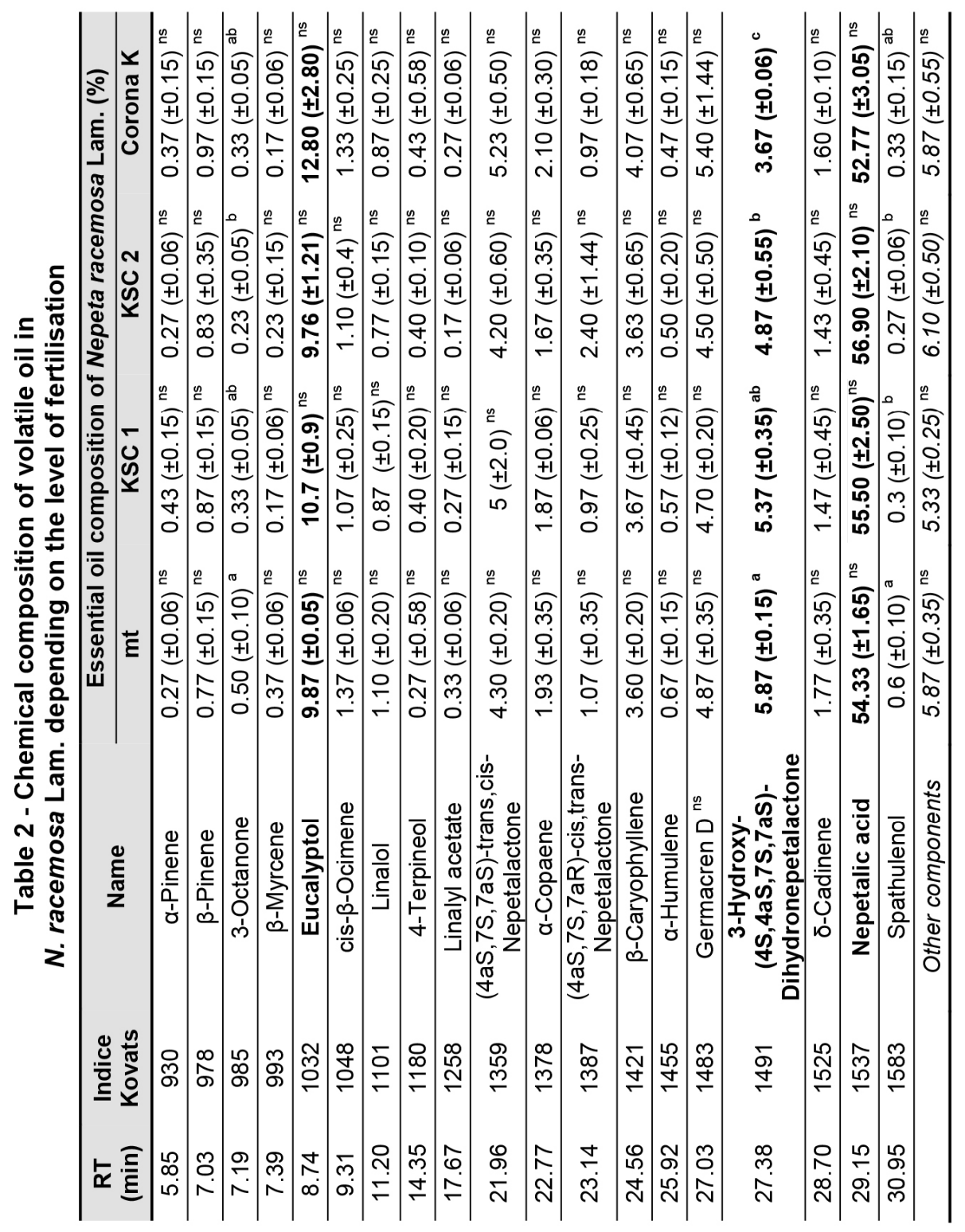


According to Baxter et al. (1998), phenolic compounds include phenolic acids and polyphenols, being a secondary class of metabolites. Polyphenols provide protection against external aggression factors being made up of aromatic compounds that contain $\mathrm{OH}$ groups. They have a defining role in the growth and development of plants and in the synthesis of lignin and assimilative pigments. In addition, phenolic phytoalexins secreted by plants injured or subjected to a stress factor repel or kill some microorganisms (Bhattacharya et al., 2010). In humans, it helps to delay the aging process and reduces the risk of oxidative stress and inflammation, preventing the occurrence of chronic diseases, such as atherosclerosis, cardiovascular and neurological diseases (Minatel etal.,2017). The concentration of polyphenols in plants depends on environmental conditions, the phenophase (Lynn and Chang, 1990) and the level of fertilisation.

The highest polyphenol content was achieved at the first harvest, with $33.1 \mathrm{mg} \mathrm{GA} / \mathrm{g} \mathrm{dw}$ for the variant fertilised by Corona $\mathrm{K}$, and the lowest for the non-fertilised control variant, with $16.47 \mathrm{mg} \mathrm{GA} / \mathrm{g}$ dw. In the case of the second harvest, the largest amount was also made for the variant fertilised with potassium rich fertiliser, and the smallest for the control variant (Fig. 1).

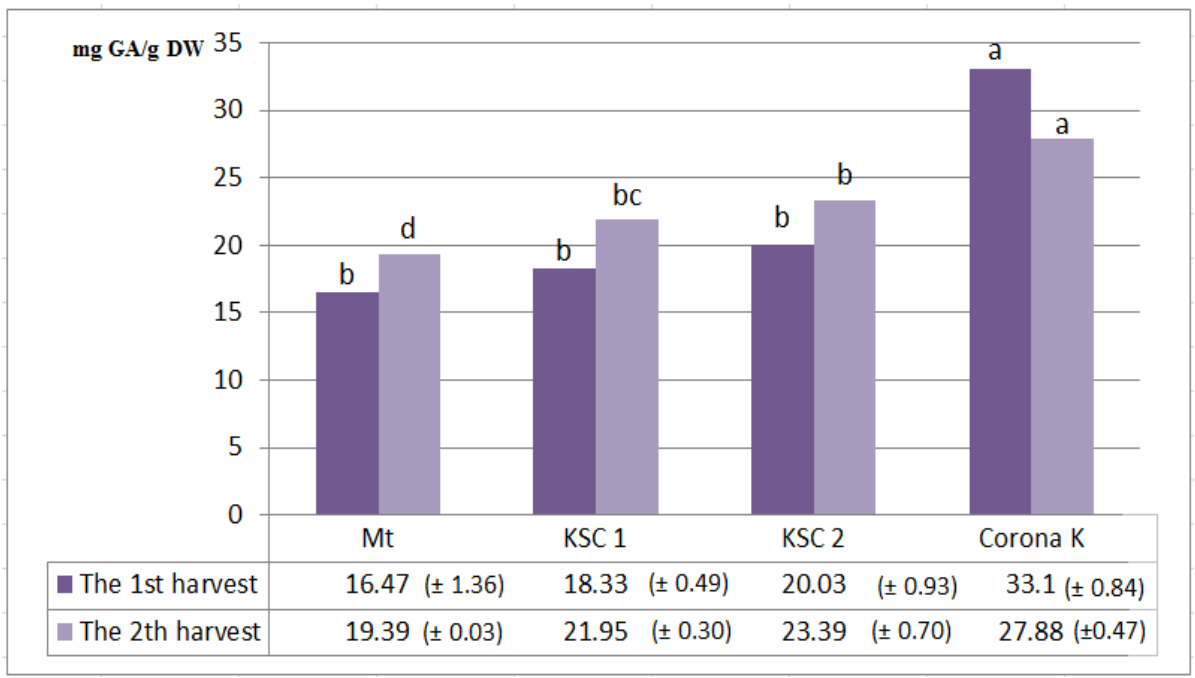

Figure 1 - Total polyphenol content of Nepeta racemosa Lam.

Flavonoids are a subclass of phenolic compounds present in various forms and with a multitude of functions in plants. Different flavonoids have diverse biological functions, including protection against UV radiation, phytopathogens, adrocyte fertility, auxin transport and flower staining as visual signals for attracting pollinators (Bradshaw and Schemske, 2003; Mathesius, 2018). They have a special role in low temperature and drought resistance and can also play a functional role in plant acclimatisation (Samanta et al., 2011). Numerous studies present the use of flavonoids in disease treatment, such as for 


\section{Constantin LUNGOCI, Carmen Doina JITĂREANU, Carmen Simona GHIȚĂU, Teodor ROBU}

cardiovascular diseases, inflammation process inhibition and immune system improvement (Panche et al., 2016).

The highest total flavonoid content was achieved at the second harvest (56.77 $\mathrm{mg} \mathrm{QE} / \mathrm{g} \mathrm{dw}$ ), followed by the nitrogen-fertilised variant $(20.39 \mathrm{mg}$ $\mathrm{QE} / \mathrm{g} \mathrm{dw})$. At the first harvest, the content was lower for the potassiumfertilised variants $(26.34 \mathrm{mg} \mathrm{QE} / \mathrm{g} \mathrm{dw}$ ) and nitrogen-fertilised variants (20.39 mg QE/g dw) (Fig. 2)

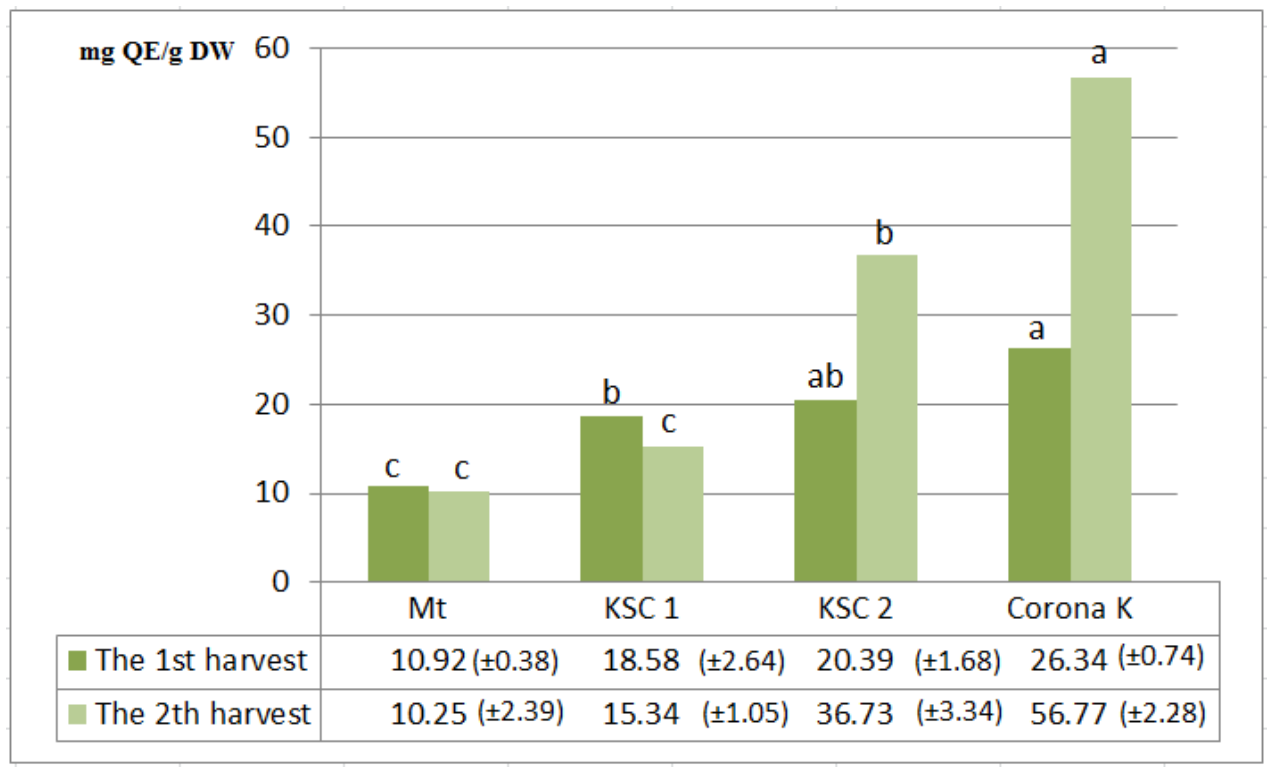

Figure 2 - Total flavonoid content of Nepeta racemosa Lam.

The antioxidant activity of phenolic compounds is caused by the ability to retain free radicals, cloning hydrogen atoms, electrons or chelated metal cations (Afanas'ev et al., 1989). Molecular structures, especially the number and position of hydroxyl groups, as well as the nature of substitutions on aromatic rings, give phenolic compounds the ability to inactivate free radicals, which is called the structure-activity relationship (SAR).

Hydrogen atoms in the adjacent hydroxyl groups (o-diphenol), arranged in different positions of the $\mathrm{A}, \mathrm{B}$ and $\mathrm{C}$ rings, the double chains of the benzene ring and the double bond of the functional group $(-\mathrm{C}=\mathrm{O})$ of some flavonoids, ensure the activity of these compounds.

Their high antioxidants. This feature can also be observed with quercetin and catechin (Rice-Evans et al., 1996).

From the analysis of antioxidant activity, we can see that the highest percentage of inhibition was achieved at the second harvest in the variant fertilised with potassium-based fertiliser $(38.54 \%)$. This can be attributed to the high content of polyphenols. In the case of the first harvest, the highest values were $21.4 \%$ for the nitrogen-fertilised variant and $22.95 \%$ for the potassiumfertilised variant (Fig. 3).

At the first harvest, the highest pigment content was observed for the 
potassium-fertilised variants (Fig. 4). All three pigments had higher values than the control variant. Chlorophyll $a$ had a significant difference from the phosphorus-fertilised and non-fertilised variants. There were no significant differences between potassium- and nitrogen-fertilised variants. The highest values were $17.68 \mu \mathrm{gg} / \mathrm{ml}^{-1}$ for chlorophyll $a, \quad 6.41 \mu \mathrm{g} / \mathrm{ml}^{-1}$ for chlorophyll $b$, and $3.34 \mu \mathrm{g} / \mathrm{ml}^{-1}$ for carotenoid pigments.

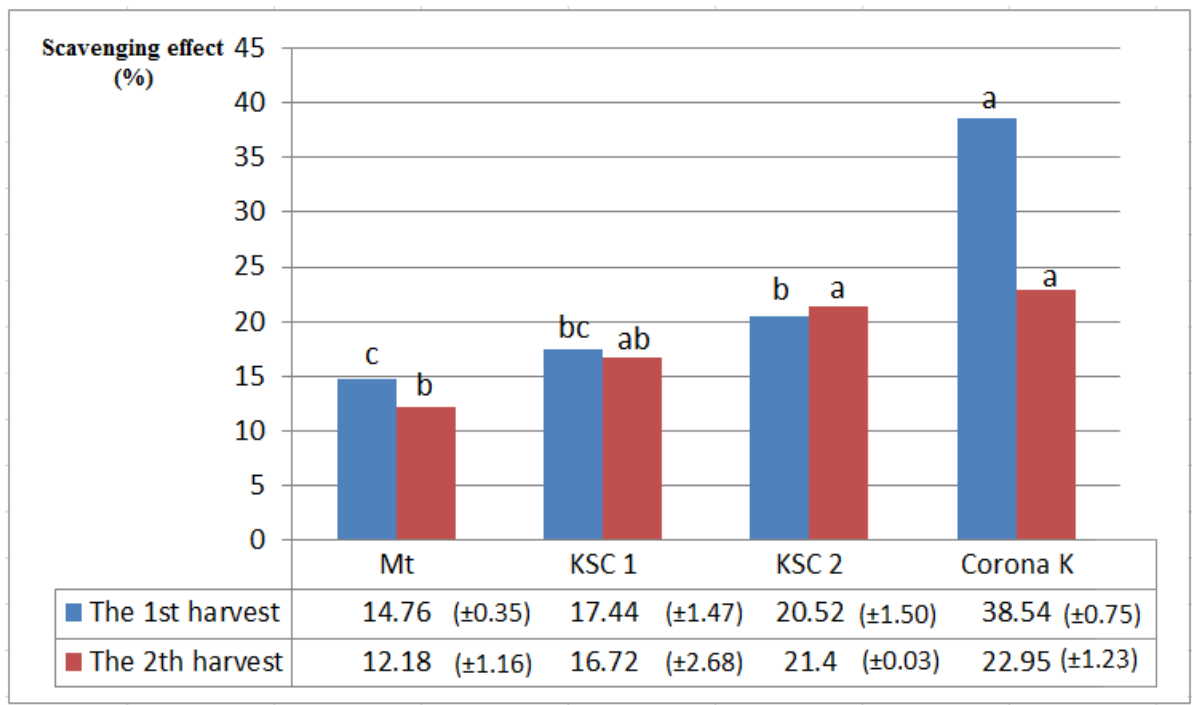

Figure 3 - Antioxidant activity in Nepeta racemosa Lam.

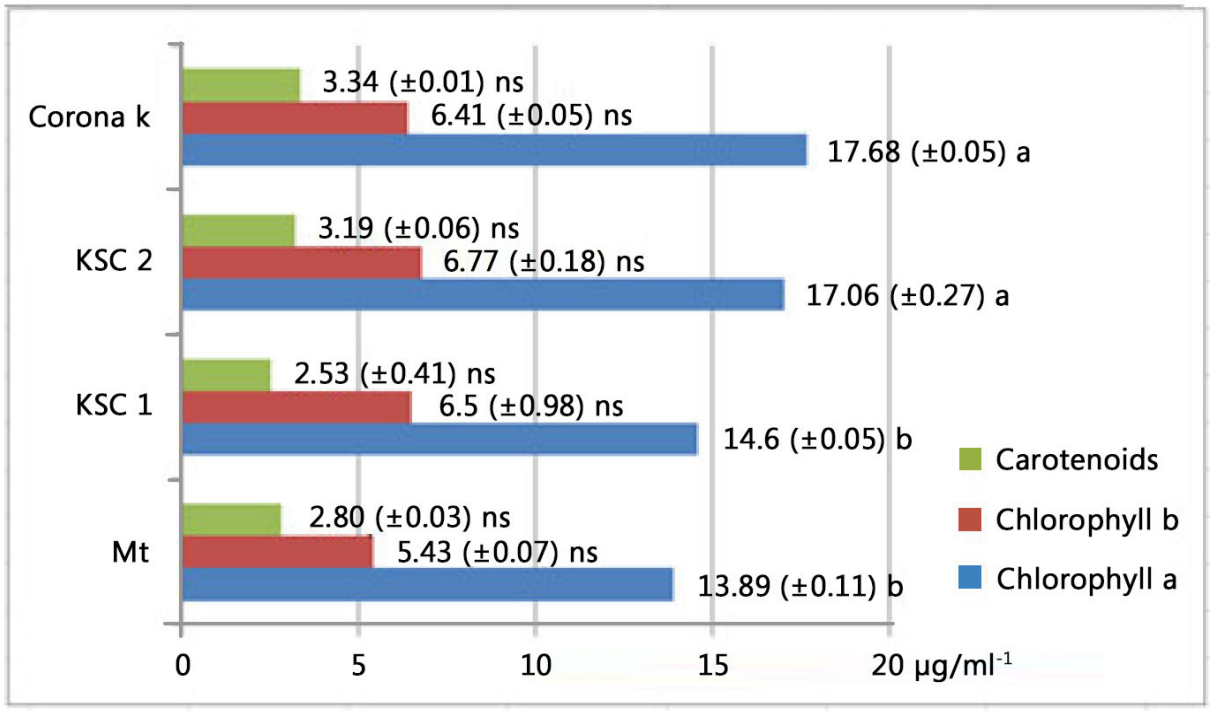

Figure 4 - Analysis of chlorophyll pigments in Nepeta racemosa Lam. from the first harvest 


\section{Constantin LUNGOCI, Carmen Doina JITĂREANU, Carmen Simona GHIȚĂU, Teodor ROBU}

At the second harvest, the chlorophyll values were similar to those obtained at the first harvest. In the case of chlorophyll $b$, the content was much higher, reaching $9.66 \mu \mathrm{g} / \mathrm{ml}^{-1}$ with a large difference from the control variant.

Carotenoid pigments had the highest value in the nitrogen-fertilised variant $\left(2.50 \mu \mathrm{g} / \mathrm{ml}^{-1}\right)$ and the lowest amount in the Corona $\mathrm{K}$-fertilised variant $\left(2.07 \mu \mathrm{g} / \mathrm{ml}^{-1}\right)$ (Fig. 5). The productions varied from one fertilisation variant to another. The highest production of $986.66 \mathrm{~g} / \mathrm{m}^{2}$, was obtained for the phosphorus-fertilised variant in the first harvest and was $861.33 \mathrm{~g} / \mathrm{m}^{2}$ in the second harvest (Fig. 6). The increase in production can also be attributed to the fact that phosphorus fertiliser acts more efficiently on the production in the phenophase in which the treatment was carried out (flowering onset) (Jităreanu, 2007; Rusu et al., 2008).

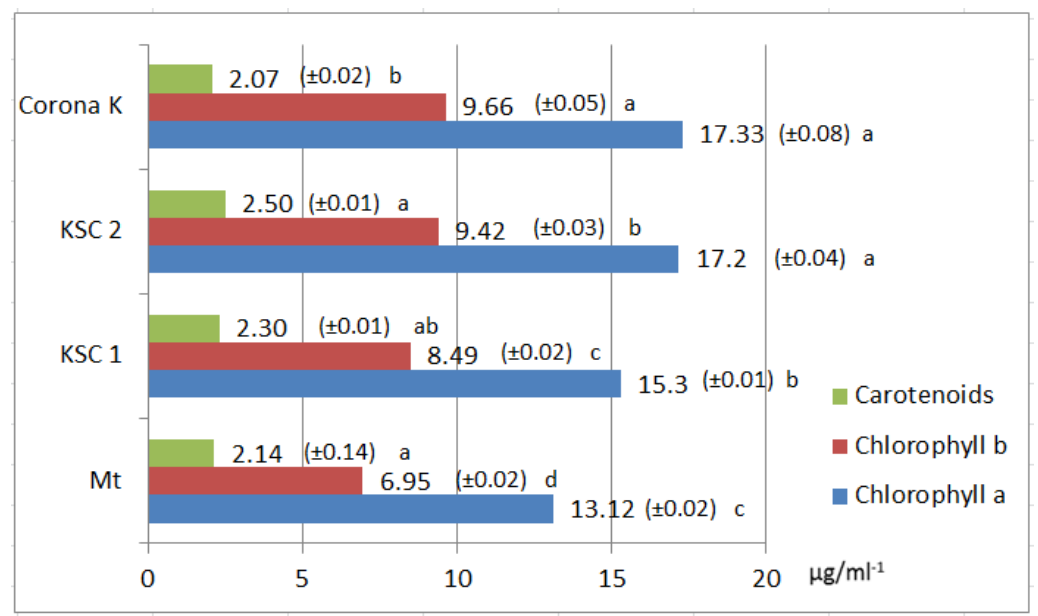

Figure 5 - Content in chlorophyll pigments in Nepeta racemosa Lam. for the second harvest

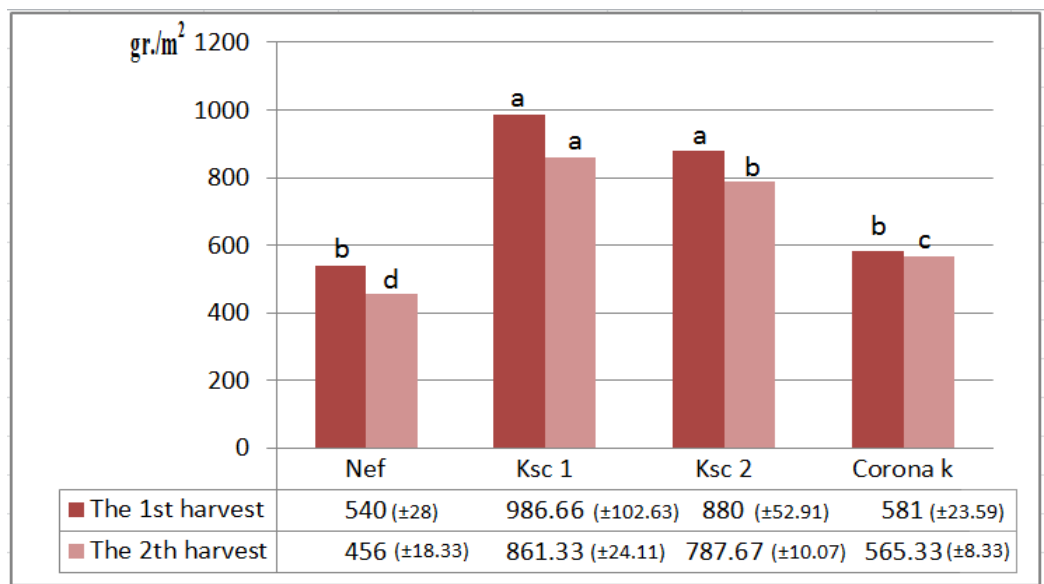

Figure 6 - Production of the two harvests of Nepeta racemosa Lam. 


\section{EVALUATION OF SOME ELEMENTS OF PHYSIOLOGY AND BIOCHEMISTRY IN NEPETA RACEMOSA LAM.}

\section{CONCLUSIONS}

Nepeta racemosa Lam. has acclimatised well in the conditions of the Moldavian forest steppe, considering that it is of southern origin. It has good grass production in two crops.

Nepeta racemosa Lam. had a different chemical composition from the results reported by other authors. Fertilisation influenced its biochemical composition, especially that of potassium.

The volatile oil has a high content of nepetallic acid, which can be used in some products or as a precursor for others after extraction.

The content of polyphenols, flavonoids, and antioxidant activity can be capitalised in obtaining products used in various industrial fields.

$N$. racemosa Lam. is suitable for the conditions of the Moldavian forest steppe area, where it can be harvested twice per year. Foliar fertilisation had a favourable effect on production, especially in the flowering phenophase. Most works report $4 \mathrm{a} \alpha, 7 \alpha, 7 \mathrm{a} \beta-$ nonpetalactones as the main component, and in our study, nepetallic acid was the main component.

\section{REFERENCES}

Adams, R.P. (2007). Identification of essential oil components by gas chromatography/mass spectrometry. $4^{\text {th }}$ Ed., Allured Publishing Co., Carol Stream, IL, USA.

Afanas'ev, I.B., Dcrozhko, A.I., Brodskii, A.V., Kostyuk, V.A. \& Potapovitch, A.I. (1989). Chelating and free radical scavenging mechanisms of inhibitory action of rutin and quercetin in lipid peroxidation. Biochem. Pharmacol.,
38(11): 1763-1769, DOI: 10.101 6/0006-2952(89)90410-3

Al-Oqail, M., Al-Sheddi, E., Siddiqui, M., Musarrat, J., Al-Khedhairy, A. \& Farshori, N. (2015). Anticancer activity of chloroform extracts and sub-fractions of Nepeta deflersiana on human breast and lung cancer cells: An in vitro cytotoxicity assessment. Pharmacogn. Mag., 11(Suppl 4): S598-S605, DOI: 10.4103/0973-1296.172968

Azizian, T., Alirezalu, A., Hassani, A., Bahadori, S. \& Sonboli, A. (2021). Phytochemical analysis of selected Nepeta species by HPLC-ESI-MS/MS and GC-MS methods and exploring their antioxidant and antifungal potentials. J. Food Meas. Charact., 15(3): 2417-2429, DOI: 10.1007/s1169 4-021-00819-8

Baxter, H., Puri, B., Harborne, J.B., Hall, A. \& Moss, G.P. (Eds.)(1998). Phytochemical Dictionary - A Handbook of Bioactive Compounds from Plants. $2^{\text {nd }}$ Ed., Taylorand Francis Group, p. 360, DOI: $10.4324 / 9780203483756$

Bhattacharya, A., Sood, P. \& Citovsky, V. (2010). The roles of plant phenolics in defence and communication during Agrobacterium and Rhizobium infection. Mol. Plant Pathol., 11, 705719, DOI: 10.1111/j.13643703.2010. 00625.x

Botnar, Diana Geanina (2011). Research regarding the influence of biological and technological factors, concerning production and quality of potato, in the ecological conditions of the Moldavian Plain, for sustainable agriculture (in Romanian), Doctoral thesis, UASVM lasi.

Bradshaw, H.D. \& Schemske, D.W. (2003). Allele substitution at a flower colour locus produces a pollinator shift in monkeyflowers. Nature, 426: 176-178, DOI: 10.1038/nature02106

Buhăianu, S. \& Jităreanu, Carmen Doina (2018) Variations of foliar pigments content at Abies alba and Nepeta pannonica species from three different areas of Bucovina, in growing and flowering phenophases. Lucr. Ştiinţ., Seria Agronomie, 61(1): 67-70, UASVM lasi, Romania. 


\section{Constantin LUNGOCI, Carmen Doina JITĂREANU, Carmen Simona GHIȚĂU, Teodor ROBU}

Çalmaşur, O., Aslan, I. \& Sahin, F. (2006). Insecticidal and acaricidal effect of three Lamiaceae plant essential oils against Tetranychus urticae Koch and Bemisia tabaci Genn. Ind. Crops Prod., 23(2): 140-146, DOI: 10.1016/j.indcrop. 2005.05.003

Dabiri, M. \& Sefidkon, F. (2003). Chemical composition of the essential oil of Nepeta racemosa Lam. from Iran. Flavour Fragr. J., 18(2): 157-158, DOI: 10.1002/ffj. 1151

Filipov, F. (2005). Soil Science (in Romanian). Publishing House Ion lonescu de la Brad, lasi. ISBN: 973-7921-64-X.15.

Harney, J.W., Barofsky, I.M. \& Leary, J.D. (1978). Behavioral and toxicological studies of cyclopentanoid monoterpenes from Nepeta cataria L. Lloydia, 41(4): 367-374.

Işcan, G., Köse, Y.B., Demirci, B. \& Başer, K.H.C. (2011). Anticandidal activity of the essential oil of Nepeta transcaucasica Grossh. Chem. Biodivers., 8(11): 2144-2148, DOI: 10.1002/cbdv.201100091

Jităreanu, Carmen Doina (2007). Plant Physiology (in Romanian). Publishing House Ion lonescu de la Brad, Iasi, ISBN 973-7921-89-5, p.153.

Kordali, S., Tazegul, A. \& Çakir, A. (2015). Phytotoxic effects of Nepeta meyeri Benth. extracts and essential oil on seed germinations and seeding growths of four weed species. Rec. Nat. Prod., 9(3): 404-418.

Lichtenthaler, H.K. (1987) Chlorophylls and carotenoids: pigments of photosynthetic biomembranes. Methods Enzymol., 148: 350-382, DOI: 10.1016/00766879(87)48036-1

Lobiuc, A., Vasilache, V., Oroian, M., Stoleru, T., Burducea, M., Pintilie, 0. \& Zamfirache, M.M. (2017). Blue and red LED illumination improves growth and bioactive compounds contents in acyanic and cyanic Ocimum basilicum L. microgreens. Molecules, 22(12): 2111, DOI: $10.3390 /$ molecules22122111

Lynn, D.G. \& Chang, M. (1990). Phenolic signals in cohabitation: implication for plant development. Annu. Rev. Plant Physiol. Plant Mol. Biol., 41: 497-526,
DOI: 10.1146/annurev.pp.41.060190.0 02433

Mohammadhosseini, M. (2016). Screening of the profiles of the essential oils from the aerial parts of Nepeta racemosa using classical and microwave-based methods: Comparison with the volatiles using headspace solid-phase micro-extraction. Journal of Herbal Drugs, 7(2): 97-108.

Mathesius, U. (2018). Flavonoid functions in plants and their interactions with other organisms. Plants, 7(2): 30, DOI: 10.3390/plants7020030;

McElvain, S.M. \& Eisenbraun, E.J. (1955). The constituents of the volatile oil of catnip. III. The structure of nepetalic acid and related compounds. J. Am. Chem. Soc., 77(6): 1599-1605.

Minatel, I.O., Borges, C.V., Ferreira, M.I., Gomez, H.A.G., Chen, C.-Y.O. \& Lima, G.P.P. (2017). Phenolic compounds: Functional properties, impact of processing and bioavailability. In: Phenolic Compounds (Ed. Marcos Soto-Hernandez), IntechOpen, https://doi.org/10.5772/66368

Morteza-Semnani, K. \& Saeedi, M. (2004). Essential oils composition of Nepeta cataria L. and Nepeta crassifolia Boiss. \& Buhse from Iran. J. Essent. Oil-Bear. Plants, 7(2): 120-124, DOI: 10.1080/0972-060X.2004.10643376

Mutlu, S., Atici, O. \& Esim, N. (2010). Bioerbicidal effects of essential oils of Nepeta meyeri Benth. on weed spp. Allelopathy J., 26(2): 291-300.

Onofrei, V., Teliban, G.-C., Burducea, M., Lobiuc, A., Sandu, C.B., Tocai, M. \& Robu, T. (2017). Organic foliar fertilization increases polyphenol content of Calendula officinalis L. Ind. Crops Prod., 109: 509-513, DOI: 10.1016/j.indcrop.2017.08.055

Panche, A.N., Diwan, A.D. \& Chandra, S.R. (2016). Flavonoids: an overview. J. Nutr. Sci., 5, DOI: 10.1017/jns.2016.41

Pavela, R., Žabka, M., Vrchotová, N. \& Tř́íska, J. (2018). Effect of foliar nutrition on the essential oil yield of thyme (Thymus vulgaris L.). Ind. Crops Prod., 112: 762-765, DOI: 10.1016/j.in dcrop.2018.01.012 


\section{EVALUATION OF SOME ELEMENTS OF PHYSIOLOGY AND BIOCHEMISTRY IN NEPETA RACEMOSA LAM.}

Peterson, C. \& Coats, J.R. (2001). Insect repellents - past, present and future. Pestic. Outlook, 12(4): 154-158, DOI: 10.1039/b106296b

Rather, M.A., Hassan, T., Dar, B.A., Shawl, A.S., Qurishi, M.A. \& Ganai, B.A. (2012). Essential oil composition of Nepeta raphanorhiza Benth. growing 2 in Kashmir valley. Rec. Nat. Prod., 6(1): 33-38.

Rice-Evans, C.A., Miller, N.J. \& Paganga, G. (1996). Structure-antioxidant activity relationships of flavonoids and phenolic acids. Free Radic. Biol. Med., 20(7): 933-956, DOI: 10.1016/0891-5849(95) 02227-9

Romanian Farmacopoeia (2008). Medical Publishing House (in Romanian), Bucharest, pp. 1046-1064.

Rustaiyan, A., Khosravi, M., Larijany, K. \& Masoudi, S. (2000). Compostion of the essential oil of Nepeta racemosa Lam. from Iran. J. Essent. Oil Res., 12(2): 151-152, DOI: 10.1080/10412905.20 00.9699485

Rusu, M. et al. (2008). Treatise on Agrochemistry (in Romanian). Publishing House Ceres, Bucharest, $670 \mathrm{p}$.

Salehi, B. et al. (2018). Nepeta species: From farm to food applications and phytotherapy. Trends Food Sci.
Technol., 80: 104-122, DOI: 10.1016/j.ti fs. 2018.07 .030

Samanta, A., Das, G. \& Das, S. (2011). Roles of flavonoids in plants. Int. J. Pharm. Sci. Tech., 6: 12-35.

Sârbu, I., Ştefan, N. \& Oprea, A. (2013). Vascular plants of Romania. An illustrated field guide (in Romanian). Publishing House Victor $B$ Victor, Bucharest, ISSN: 1223-6578, pp. 648650.

Sonboli, A., Salehi, P. \& Yousefzadi, M. (2004). Antimicrobial activity and chemical composition of the essential oil of Nepeta crispa Willd. from Iran. Z. Naturforsch. C.J. Biosci., 59(9-10): 653-656, DOI: 10.1515/znc-2004-91008

Teliban, G.-C., Stoleru, V., Burducea, M., Lobiuc, A., Munteanu, N., Popa, L.-D. \& Caruso, G. (2020). Biochemical, physiological and yield characteristics of red basil as affected by cultivar and fertilization. Agriculture, 10(2): 48, DOI: 10.3390/agriculture 10020048

Wellburn, A.R. (1994). The spectral determination of chlorophylls $a$ and $b$, as well as total carotenoids, using various solvents with spectrophotometers of different resolution. J. Plant Physiol., 144(3): 307-313, DOI: 10.1016/s0176-1617(11) 81192-2. 